DEPARTMENT OF THE INTERIOR

UNITED STATES GEOLOGICAL SURVEY

PREPARED IN COOPERATION WITH THE

COLORADO MINING INDUSTRIAL DEVELOPMENT BOARD AND THE

COLORADO GEOLOGICAL SURVEY

\title{
AEROMAGNETIC MAP OF COLORADO
}

By

Isidore Zietz and John R. Kirby, Jr.

GEOPHYSICAL INVESTIGATIONS

MAP GP-880

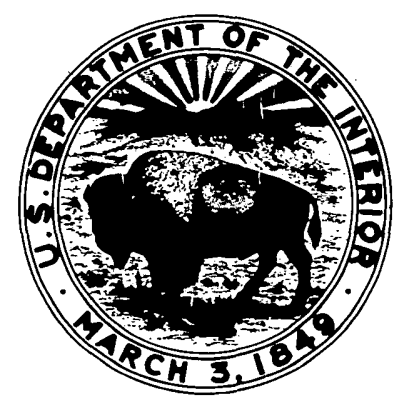

